\title{
İşrakî Teodisenin İslam Düşüncesindeki Yeri
}

\section{Selçuk GÜZEL}

Öz: Tanrı'ya inananların ve inanmayanların arasında tartışılan en önemli problemlerden biri kötülüktür. Kötülük olgusu insanoğlunun karşısında bazen kendi yaşadığı bazen başkalarında müşahede ettiği bir gerçeklik olarak durmaktadır. İnanan bir kişi görmezlikten gelemeyeceği bu durumla ilgili cevaplar aramaktadır. Kötülük probleminin Tanrı inancı ile ilgili olarak karşımıza çıkardığı problemler özünde aynı olsa bile inanan kişilerin bu problemler karşısındaki tutumları özel durumlara göre birbirinden farklılık arz edebilmektedir. $\mathrm{Bu}$ çalışmada, kötülük olgusuna İşrakî düşüncenin yaklaşımının ne olduğu anlaşılmaya çalışılacaktır. İslam düşüncesinde kötülük problemiyle ilgili kelamcılar, tasavvufçular ve filozoflar tarafından ortaya konulan açıklamalar özet bir şekilde sunulduktan sonra İşrakî düşüncenin kötülük problemi karşısında geliştirdiği teodise ve bu teodisenin İslam düşünce sistemi içerisinde durduğu yer belirlenmeye çalışılacaktır. Böylece teosofik bir anlayış olarak varsayılan İşrakî düşünce sisteminin kullandığı argümanların hangi alana yakın olduğu ortaya konmaya çalışlacaktır.

Anahtar Kelimeler: Kötülük, Teodise, Zorunlu Varlık, İşrakîlik.

\section{Place of Ishraqi Theodicy in Islamic Thought}

Abstract: Evil is one of the most important problems discussed among who believe in God and who do not believe. The phenomenon of evil stands as a reality that human beings sometimes experience in their own lives and sometimes in others. In this situation, the believer seeks answers as he/she cannot ignore it. Although the problems arising from the problem of evil are the same in terms of belief in God in essence, the answers given by the believer to it vary in accordance with particular problems. This study, focuses on Ishraqi approach to the phenomenon of evil. Having summarized major responses to evil in Islamic thought by Muslim theologians, Sufis and philosophers, it is our aim to determine the answers given to the problem of evil in the Ishraqi thought and where they stand in the Islamic thought system. In this way, it will be put forward to which area the arguments used by the Ishraqi thought system, which is presented as a theosophical understanding, are close.

Keywords: Evil, Theodicy, Necessary Being, Ishraqi. 


\section{Giriş}

Kötülük nedir? Yeryüzünde insanlar tarafından müşahede edilen veya kişinin kendisinin tecrübe ettiği acılar, ölen veya birileri tarafından öldürülen masum çocuklar, orman yangınlarında ölen masum canlılar, sel, deprem, kasırga vb. doğal afetler sonucu ölen insanlar ve canlılar bunların tümüne baktığımız vakit bunlar kötülük müdür, kötülük ise bu kötülükler gerçek midir yoksa bir yanılsama mıdır? Kötülüğün yaratıcısı Tanrı mıdır yoksa kötü fiillerin sorumlusu insan mıdır? Eğer Tanrı ise neden bu kötülükleri engellememektedir? Anlaşılan o ki kötülüğün insanı yüz yüze bıraktığı soru ve sorunlar üzerinde derinlemesine düşünülmesi ve cevaplanması gereken soru ve sorunlardır.

İslam düşüncesi içerisinde tasavvufçuların, kelamcıların ve filozofların kötülük problemine yaklaşımları kimi zaman farklılıklar kimi zaman da benzerlikler arz etmektedir. Makaledeki temel amaç, genel olarak tasavvuf ve felsefenin metotlarını kullandığı kabul edilen teosofik İşrakî düşünce sisteminin kötülük problemine vermiş olduğu cevapların neler olduğunun ortaya konulmasıdır. Yine teosofik düşünme biçimine sahip olduğu iddia edilen İşrakî düşüncenin bu problem karşısındaki cevabının gerçekten teosofik mi, kelamî mi yoksa başka bir şey mi olduğu sorusunun da cevabı aranacaktır. Böylece kötülük problemi karşısında İşrakîlerin özgün bir cevaplarının da olup olmadığı ortaya çıkacaktır.

İyinin karşıtı olan, beğenilmeyerek kınanan, hür iradenin reddettiği ve kurtulmaya çalıştığı her şey olarak tanımlayabileceğimiz kötülük kavramı aslında gerçek dünyada insanın karşısında durmaktadır. ${ }^{1}$ Evrende var olan kötülüğün iyi olarak nitelenen bir Tanrı anlayışı ile bağdaşmasında ortaya çıkan kötülük probleminin tarihi eskilere dayanmaktadır. Mantıksal olarak bunu ilk formülleştiren Epikuros'un formülasyonunu M.S. II. yy.da yaşamış olan kilise rahibi olan Lactantius şu şekilde aktarır:

"Tanrı, ya kötülükleri ortadan kaldırmak ister de kaldıramaz veya kaldırabilir, ama kaldırmak istemez; ya da ne kaldırmak ister ne de kaldırabilir yahut hem kaldırmayı ister hem de kaldırabilir. Eğer ortadan kaldırmak istiyor da kaldıramıyorsa, O güçsüzdür ki bu durum Tanrı́nın karakteriyle uyuşmaz; eğer ortadan kaldırabiliyor fakat kaldırmak istemiyorsa, O kıskançtır ki bu da aynı şekilde Tanrı ile uyuşmaz; eğer ne ortadan kaldırmayı 


\section{Selçuk GÜZEL \\ İşrakî Teodisenin İslam Düşüncesindeki Yeri}

istiyor ne de kaldırabiliyorsa hem kıskanç hem güçsüzdür, bu durumda da Tanrı değildir; eğer hem ortadan kaldırmayı istiyor hem de kaldırabiliyorsa ki yalnızca bu Tanrı'ya uygundur, o zaman kötülüklerin kaynağı nedir? Ya da O kötülükleri niçin ortadan kaldırmamaktadır?".2

David Hume, "Din Üstüne" isimli eserinde bu problemi şu şekilde tekrar dile getirmiştir:

"Epikuros'un eski soruları hala yanıtlanmamıştır: "Tanrı kötülüğü önlemek istiyor da buna gücü mü yetmiyor? O zaman güçsüzdür. Gücü yetiyor da önlemek mi istemiyor? O zaman kötü niyetlidir. Hem gücü yetip hem de önlemek isteyen bir Tanrı ise kötülük nereden geliyor?"3

Hume'un bu formülasyonundaki vurgulanan husus, Tanrı́nın ezeli ilmi ile varlık için öncenin ve sonranın bilgisine sahip olmasından dolayı kötü eylemlere kudret sahibi olarak engel olmamasıdır ki bazı filozoflar bundan dolayı gelecekteki olaylar hakkındaki bilgisini yâdsıma yoluna gitmişlerdir. ${ }^{4}$ Bu düşünce kötülük problemine cevap verilirken Tanrı'nın kudret sıfatına zarar vermemek adına ilim sıfatına bir şekilde sınırlandırma getirmektedir ki bu da beraberinde Tanrı'nın cüz'ileri bilemeyeceği sonucunu doğurmaktadır.

Bu şekilde ortaya atılan kötülük problemi agnostik, şüpheci ve ateistlerin Tanrı karşısında en önemli dayanaklarından birisidir. Epiküros'un dile getirdiği ve David Hume tarafından formüle edilen akıl yürütme biçimine karşı bazı teistler kötülüğün reel varlığını inkâr etmişler, bazıları insanın mükemmelleşmesi için bir araç olduğunu savunmuş, bazıları da Tanrı ile ilgili sıfatları sınırlandırarak cevap vermeye çalışmışlardır. Binaenaleyh, bazılarına göre kötülük gibi görünen şeylerin küllî düzen içerisinde iyilik olarak anlaşılması gerektiği, bazılarına göre ise iyiliğin asıl, kötülüğün arızî bir durum olduğu ve iyiliğe nispetle kötülüğün evrenin sistemini tamamlaması açısından az da olsa var olduğu savunulmuştur. Bununla beraber her şey zıddıyla kaim olduğundan dolayı kötülük olmadan iyiliğin fark edilemeyeceği bundan dolayı az da olsa kötülüğün var olması gerektiği delili de ileri sürülmüştür. ${ }^{5}$

2 Cafer Sadık Yaran, Kötülük ve Teodise, (Ankara: Vadi Yayınları, 1997), 11-12.

3 David Hume, Din Üstüne, çev. Mete Tunçay, 4. Baskı, (Ankara: İmge Kitabevi Yayınları, 2004), 231.

4 Gottfried Wilhelm Leibniz, Theodicee Ya da Tanrının Haklı Kılınması, çev. Levent Özşar, (İstanbul: Biblos Kitabevi, 2009), 74 
Kötülük problemi karşısında ortaya konulan savunmalar teodise olarak isimlendirilmektedir. ${ }^{6}$ Ilk kez Gottfried Wilhelm Leibniz tarafından kullanılan Grekçe Tanrı ve adalet kavramlarından oluşturulan teodise kavramı özelde, Tanrı́nın insana karşı muamelesini haklı çıkarma teşebbüsü; genelde ise Tanrı́nın yaratmaya ilişkin ilgi ve iradesini göstermeye ilişkin kullanılan bir kavramdır.?

Leibniz kötülüğü metafizik, fiziksel ve törel kötülük olarak tasnif etmiştir. Metafizik kötülük varlığın tam yetkin olmamasından, fiziksel kötülük acı çekmekten, törel kötülük ise insanın fiillerinden yani günahlarından kaynaklanmaktadır. Genel olarak kötülük diğer filozoflar ve teologlar tarafından da metafizik kötülük, tabiî kötülük ve ahlakî kötülük olarak tasnif edilmektedir. Metafizik ve tabiî kötülük varlığı itibarıyla eşyanın yetkinliğinin eksik olması olarak tanımlanırken, ahlaki kötülük ise insana atfedilen zulüm, düşmanlık, kıskançlık gibi olumsuz sıfatlar için kullanılan bir türdür. ${ }^{9}$

Tanrı'nın adalet, kudret, ilim ve rahmet sıfatları, ortaya koyulan teodiselerin kötülük olgusuna karşı savunduğu sıfatlardır. Bu sıfatların kötülük ile ilişkisi çözümlenmeye çalışııırken önemli olan husus Tanrı'nın bu sıfatlarına zarar vermemektir. Bu sıfatlar üzerindeki mutlak vurgu hangi tarafa doğru kayarsa bir diğerine zarar verecektir. ${ }^{10}$ Tanrı tarafından yaratılan her şey bu ilahi sıfatların kapsamı içerisinde yer almaktadır. Bu kapsam içerisinde var olan Tanrısal sıfatları açıklarken sıfatların birbiriyle olan ilişkisini de göz ardı etmemek gerekir. Bundan dolayı bu sıfatlardan birini zayıflatmak veya yok saymak, kötülük olgusuna karşı ortaya koyulan teodiselerin geçerliliğine ve kendi içerisindeki tutarlıığına zarar verecektir.

Bu bağlamda kötülük olgusu inanmayanların olduğu kadar inananların da üzerinde düşünmesi gereken bir problem olarak karşımıza çıkmaktadır. İnanmayanların kötülük problemi üzerinden yönelttiği sorulara teolojik ve felsefî gelenekler farklı cevaplar vermişlerdir. Verilen cevapların farklı olmasının sebebi Tanrı, evren, insan, özgürlük, ahiret anlayışlarından kaynaklanmaktadır. ${ }^{11}$ Öz itibarıyla

Savunma, kötülük probleminin belli bir formulasyonunun teizmin öğretilerini çürütmekte başarısız olduğunu ortaya çıkarmaktır. Teodise ise Tanrı́nın var olan kötülüğe neden engel olmadığının makul bir teistik açıklamasıdır. Detaylı bilgi için bkz. Yaran, Kötülük ve Teodise,41.

8 Leibniz, Theodicee, 127.

9 Özdemir, Kötülük Problemi, 19-29.

10 Ormsby, illahi Adalet Sorunu, 16.

11 Yaran, Kötülük ve Teodise, 13. 
baktığımız zaman bu kavramların anlamlandıııması yine Tanrı üzerindendir. Bundan dolayı aslında Tanrı'nın sıfatlarının bu kavramlar ile ilişkilendirilmesindeki farklılıklar verilen cevapları da farklılaştırmaktadır.

İslam düşüncesinde kötülük kavramı için kullanılan en önemli kavram şer olmakla beraber bazen onun yerine cevr ve zulüm kavramları da kullanılmaktadır. Şer kavramı hiç kimsenin arzulamadığı, istemediği uzak durduğu her şeyi ifade eder ve hayr kavramının zıddıdır. ${ }^{22}$ Kur'ân-ı Kerim'de de şer kelimesine yakın anlam taşıyan durr, fahşa, fesad, musibet, seyyie ve sû' kavramları bulunmaktadır. ${ }^{13}$ Islam düşüncesinde şer bir problem olarak ele alınmakla beraber ortaya koyulan savunma veya teodiselerin dayandığı temel argümanlar vahiy kaynaklıdır yani bu probleme cevap verilirken vahiy göz ardı edilmemiştir. Tasavvufta nefs kavramı üzerinden ele alınarak cevap verilen şer kavramını kelamcılar kubuh kavramı çerçevesinde ele almışlardır. Ayrıca Mu'tezilî düşüncenin (ileride detaylı olarak açıklayacağımız) ortaya koyduğu aslah kavramı da yani Tanrı'nın kulları için maslahatı gözetmesi zorunluluğu şer problemine verdikleri cevaplar bağlamında önemli bir yeri haizdir. İslam filozoflarına baktığımız zaman ise genel itibarıyla bu problem metafizik ve ahlak başlıkları içerisinde ele alınmıştı. Özellikle Meşşaî filozofların savundukları sudur teorisi bu problemin ortadan kaldırılması için verdikleri cevapların temelini oluşturmaktadır.

Öncelikli olarak İslam düşüncesinde kötülük problemine verilen cevapları tam anlamıyla kavrayabilmek adına vahyin bu problem karşısında ortaya koyduğu duruşa bakmak gerekmektedir. Kötülük probleminin ortaya çıkardığı sorulara ve sorunlara yönelik Kur'ân-ı Kerim'de bulunan cevapları imtihan ve eğitim, disiplin ve ceza, ahiret, cüzî̀ iradenin hatalı kullanılması ana başlıkları altında toplayabiliriz. Kuranî anlayışa göre musibetler doğru değerlendirildiği takdirde manevi ve dini eğitimin bir aracı olarak görülmektedirler (A'raf, 94). Musibetler psikolojik olarak insana daima Tanrı'yı kudret ve yaratıııs açısından hatırlamasının, insanın O'nun emir ve yasaklarına uyup uymadığı noktasında kendi içe dönüşünü yaşayarak iç muhasebesini yapmasının bir aracı olarak önemli bir yeri haizdir. ${ }^{14}$ Kötülük problemi bu dünya hayatında yaratılan sisteme bütüncül olarak bakılabildiği zaman tutarlı bir çözüme kavuşabilir. Kur'an-ı Kerim'de ifade ettiği üzere Allah bu ları,2012), 519, 791. 
dünyayı bir imtihan yeri olarak yaratmış ve bu imtihanın amacına hizmet edebilmesi yani insanın sınanabilmesi için her türlü inceliği içeren düzen yerli yerine yerleştirilmiştir (Mülk, 1). Sadece varlığın değil aynı zamanda düzeninde kaynağı olan Allah, insana imtihan için emir ve yasaklar bağlamında bir sorumluluk yüklemiş; ayrıca sorumluluk verdiği insanoğluna bunu unutmaması, bilincini ve ilgisini sürekli canlı tutması için kimi zaman musibet ve belalar isabet ettirmiştir. ${ }^{15}$ İmtihan dünyası içerisinde musibet ve belaların olmaması insanın sorumluluğunu unutmasına sebebiyet vereceğinden dolayı asıl kötülük bunun sonucunda gerçekleşecektir. Zaten bir şeyin denenmesi yani imtihan olabilmesi için bu türlü zorlukların olması normal bir durumdur.

Disiplin ve ceza; "başınıza her ne musibet gelirse kendi yaptıklarınız yüzündendir. $O$, yine de çoğunu affeder" (Şura,30) ve "insanların kendi ellerinin irade ve ihtiyarıyla yaptıkları işlerden dolayı karada ve denizde fesat çıktı ki Allah işledikleri günahlarından bir kısmının cezasını dünyada onlara tattırsın, olur ki dönerler" (Rum,41) gibi birçok ayet-i kerimede zikredildiği üzere insanın ahlaki davranışlarının kötü olmasından dolayı Tanı tarafından tabii kötülük denilen doğal afetlere maruz kalabileceği bildirilmektedir. ${ }^{16}$ Gerçek adalet yurdu olarak ahiret; Kur'ân'ın kötülükler karşısında cevaplarından biridir. Allah'ın adaletinin ve insanı imtihan etmesinin zorunlu sonucu ahirettir ki insanın dünya hayatında emir ve yasaklar doğrultusunda yapmış olduğu tercihlerinin bir karşılığı ve sonucudur. Peygamberlerin gönderiliş gayeleri insanları uyarmak ve müjdelemektir ki bu görevin ifa edilmesinde cennet-cehennem kavramları önemli bir yer tutmaktadır. ${ }^{17}$ Ahiret inancının temeli bunlara dayanmaktadır ki insanın zerre kadar yaptığı kötülüklerin ve iyiliklerin karşılığını göreceği Allah'ın adaletinin tam olarak gerçekleşeceği, insanların dünyadaki fiillerinin karşılığı olarak ya ebedi saadete ve yahut da acıya ulaşacağı düşüncesi, dünyadaki kötülüklerin ve musibetlerin sabır ile karşılanmasının insandaki psikolojik dayanağıdır. Cüz'i iradenin hatalı kullanılması; ahlaki fiillerin sorumluluğunun insana yüklenebilmesi açısından insanın yapmış olduğu fiillerinde özgür iradesinin ve hürriyetinin olması gerekmektedir. Bunun aksinde ise insanın yapmış olduklarından dolayı sorumlu tutulması Bazı Değerlendirmeler", EKEV Akademi Dergisi 35 (2008), 22.

17 Ömer Özsoy, İlhami Güler, Konularına Göre Kur'ân (Sistematik Kur'ân Fihristi), (Ankara: Fecr Yayınları, 2004), 243. 
düşünülemez. ${ }^{18}$ Sorumluluk olmazsa imtihan olmayacağından, imtihan olmazsa bunun bir karşılığı düşünülemeyeceğinden dolayı da insanın yaratılışının bir anlamı kalmayacaktır. Bundan dolayı özgür iradeye sahip bir varlık olan insanın yaptıklarından dolayı sorumlu olması ve bu sorumluluğun sonucunda da doğal olarak bir karşılık görmesi tutarlı bir durumdur. Tutarsız olan, bu kavramlardan birini iptal etmeye çalışmaktır.

Kötülük problemine Kur'ân-ı Kerim'in ayetler üzerinden vermiş olduğu cevaplar özet olarak yukarıdaki gibidir. İşrakî düşüncenin kurucusu olarak kabul edilen Sühreverdî́nin evren ve varlık tasavvurunu üzerine bina ettiği kavram “Allah göklerin ve yerin nurudur" (Nur, 35) ayetindeki nur kavramıdır. İşrakîler kötülük problemine karşı ortaya koydukları argümanlarda da bu kavramı ön plana çıkarırlar. Bundan dolayı İşrakîlerin kötülük probleminde vahyi argümanları arasında kullanarak göz ardı etmediklerini açıkça ifade edebiliriz. Bu husus makalenin İşrakî teodise bölümünde daha açık bir şekilde ortaya çıkacaktır. İşrakî teodisenin İslam düşünce sistemi içerisindeki bulunduğu konumu belirleyebilmek adına buna ek olarak tasavvufçuların, kelamcıların ve filozofların bu probleme yaklaşımlarına bakmak gerekmektedir.

\section{Tasavvufta Kötülük Probleminin Ele Alınışı}

Tasavvufta kötülük probleminin ele alınarak incelenmesi için nefis kavramına bakmak gerekmektedir. Çünkü tasavvuf ehli, kötülüğün kaynağı olarak "Ben nefsimi temize çıkarmam, çünkü Rabbimin merhamet ettiği hariç, nefis aşırı derecede kötülüğü emreder" (Yusuf, 53) ayet-i kerimesinde geçen nefs-i emmareyi yani kötülüğü emreden nefsi görürler.

Tasavvuf ehli nefis konusunda; nefsin mahiyeti, birliği, cisim olup olmayışı, kadim veya hâdis oluşu vb. felsefeci ve kelamcıların tartıştıkları problemlerden öte nefsin zaafları, hastalıkları ve bunlardan kurtuluş yollarını ortaya koymaya çalışmıştır. ${ }^{19}$ Tasavvuf nefis ve ruh temizliğini esas alarak tezkiye, riyazet, zikir, dua ve tevbe vb. yöntemler ile salîkin ruh olgunluğuna erişmesini amaçlamaktadır. Bu amacın yani nefis terbiyesi ve ahlakı güzelleştirmenin sebebi ise mutlak varlık olarak gördükleri Tanrı ile ilişki kurmaktır. ${ }^{20}$ 
Tasavvufta; nefsin ilahi olanın emrine uyarak ve nefis tezkiyesi ile ulaşacağı atvâr-ı sebâ denilen yedi mertebesi vardır ki bunların en başında yukarıda da Yusuf suresinde belirttiğimiz ayette geçen nefs-i emmare gelir. Diğerleri ise nefs-i levvame, nefs-i mülhime, nefs-i mutmaine, nefs-i raziye, nefs-i marziyye ve nefs-i zekiye veya kâmile olarak isimlendirilmektedir. ${ }^{21}$ Insanın natık nefsi, ulvî ruhtan gelen nur ve hayvanî-tabiî ruh bileşkesinden meydana gelmektedir. Tasavvuf ehli, "nefse ve ona bir düzen içinde biçim verene, sonra ona fücurunu ve takvasını (iyiliği ve kötülüğü) ilham edene" (Şems, 8) ayet-i kerimesinde ifade edildiği gibi insanî nefste kötülüğün ve iyiliğin meyil açısından var olduğunu kabul eder. ${ }^{22}$

Tasavvuf ehline göre insandaki kötü ahlakın kaynağı ve yerilmiş sıfatların mahalli olarak görülen nefis; heva, nifak, riya, kendini beğenmişlik, cimrilik, hırs, tamah gibi olumsuz sıfatlardan sıyrılmadan ilahî olana ulaşmada bir yol kat edemez. Çünkü nefis her zaman hissî lezzetlere ve şehvetlere ulaşmayı arzular; nefsin yaratılmış olduğu dört tabiat unsuru olan sıcaklık, soğukluk, rutubet ve kuruluktan kaynaklanan nefsanî sıfatların kötü olanları insanın süflî âlemin ötesine geçmesine bir engel teşkil eder. ${ }^{23}$

Kötü sıfatlar nefse ait marazlardır ve bu marazlardan kurtulmanın yollarını enbiyalar ve onların takipçileri olan evliyalar insanlara sunmuşlardır. Bu kurtulma yolları ile kötü sıfatları nefsinde ilk neşet ettiği anda tanıyarak bunlardan uzaklaşana arif, ikinci seferde buna ulaşana mütearif, hiç ulaşamayana ise gafil denmektedir. Buradan hareketle ilk anda kötü olan sıfatı görüp, tanıyıp uzaklaşana arif denmesinin sebebi marifetun-nefstir. "Nefsini tanıyan Rabbini tanır"24 tasavvufî vecizesinden hareketle tasavvuf ehli, rububiyetin marifetini nefsin marifetine meşrut ve merbut olarak görmektedir. ${ }^{25}$

Tasavvuf ehli, salik ile Hak Teâlâ arasında marifetullaha engel teşkil eden her şeye hicap yani perde ismini vermiştir. Bu perdeler ile ilgili farklı görüşler olmakla beraber ittifak halinde kabul edilen ilk ve en kalın perde nefistir. Diğer perdeler

22 İzzeddîn Mahmûd bin Ali Kâşânî Natanzî, Misbâhu'l-hidâye ve miftâhu'l-kifâye (Tasavvufun Ana Esasları), Farsçadan çev. Hakkı Uygur, 2. Basım, (İstanbul: Kurtuba Kitap, 2012), 82.

23 Kâşânî, Miftâhu'l-kifâye, 84-88.

24 Ebu Sâid el-Harrâz'ın "nefsinde olanı bilmeyen Rabbini nasıl bilebilir" sözü zamanla "nefsini bilen Rabbini bilir" şeklinde tasavvufî bir vecizeye dönüşerek zaman içerisinde hadis olarak literatüre girmiştir. Detaylı bilgi için bkz. Süleyman Uludağ, "Ma'rifet-i Nefs", Türkiye Diyanet Vakfı Islam Ansiklopedisi, (Ankara:TDV, 2003), 28: 56-57.

25 
genel olarak şehvet, çoluk çocuk tutkusu, dünya, halk, makam ve mal hırsı, riya, bencillik vb. olarak zikredilmiştir. Tasavvuf ehli, "ölmeden önce ölmek” tabiriyle bu perdelerin keşf yolu ile mükaşefe ehline açılacağına inanırlar. ${ }^{26}$ Tasavvufta bu tabir aslında insanın ahlakî olarak olumlu yönde ilerlemesine ve Allah (c.c)'a yakınlaşmasına engel olan bedenden ve buna bağlı olarak dünyevileşmeden kurtularak ruhun hürriyetini elde etmesi anlamındadır. Tasavvufta hürriyetin karşılığı tam bir kulluk ile ölmeden önce dünyadan çıkmaktır. ${ }^{27}$

Genel olarak tasavvufun kötülük ilkesine bakış açısını özetleyecek olursak; tasavvuf ehli kötülüğün kaynağı olarak nefs-i emmareyi görmekte ve bu nefsin olumsuz yönlerinden insanı kurtarmanın yollarını aramaktadır. İnsanın, nefsin mertebelerinde ilerleyerek Allah ile ilişki içine girebilmesi için tasavvufî tabirle hicabları yani perdeleri yırtması gerekir. Bu yolda yapılması gereken ilk işi marifetu'n-nefs yani kişinin kendini tanımasıdır ki bu kişinin marifetullaha ulaşmasını sağlayan yegâne yoldur.

\section{2. İslam Kelamında Kötülük Problemi}

İslam kelamında bazı önemli teolojik konulara temas edilirken, ilahi sıfatlar, kaza ve kader, insanın fiilleri vb. konularda kötülük problemi ele alınmıştır. İslam kelamında kötülük problemi Tanrı-evren ilişkisinin sağlam ve tutarlı bir şekilde anlaşılabilmesini sağlamak için ele alınmış ve Tanrı inancının meşruluğunun gösterilmesi açısından önemlidir. ${ }^{28}$

Kelam literatüründe kubuh olarak adlandırabileceğimiz kötülük meselesi; tabii, manevi ve cismani kötülük olarak da tasnif edilmektedir ki tabii kötülük varlığın yetkinlik bakımından eksik yaratılması, manevi kötülük cüzi iradeden meydana gelen günah, cismani kötülük ise âlemdeki elem, acı ve ıstırabın insanın cüzi iradesi ile ortaya çıkmasıdır. ${ }^{29}$

Husün ve kubuh meselelerinde hüküm merci olarak aklın mı naklin mi otorite olarak kabul edileceği hususunda başlıca iki bakış açısı olduğu söylenebilir. Bun430-431.

27 Mustafa Çağrıcı, íslam Düşüncesinde Ahlak, (İstanbul: Dem Yayınları, 2006), 116-117.

28 Kazanç, "Tanrı ve Kötülük", 30-31. 
lardan ilki, iyinin ve kötünün nakille bilinebileceğini iddia eden Eş'arî, diğgeri de aklın ve naklin her ikisine otorite atfeden Maturidi ve Mu'tezilî yaklaşımıdır. ${ }^{30}$

Tanrı-insan ilişkisi, şerrin kaynağı, insanın fiilleri, özgür irade vb. meselelere Mu'tezile, Maturidi ve Eş'arî ekollerinin vermiş olduğu cevaplara bakarak kötülük problemine kelami açıdan nasıl yaklaşılmış olduğunu görebiliriz. Bu açıdan şimdi bu ekollerin genel olarak kötülük problemi bağlamında ortaya çıkan soru ve sorunlara vermiş oldukları cevapları ortaya koymaya çalışacağız.

Mu'tezilî anlayışa göre Allah (c.c.) tarafından emredilen şeyler özlerinde bulunan güzellikler sebebiyle emrolunmuştur ve yasaklanan şeyler asıllarında bulunan çirkinlik sebebiyle yasaklanmıştır. Bundan dolayı akıl Mu'tezilîlere göre çirkinlik ve güzelliği ayırt edebileceğinden hüküm merci olarak görülmektedir. ${ }^{31}$

Teodise kavramının en temel öğesini oluşturan adalet Mu'tezile'nin savunduğu beş prensipten birisidir. Kendilerini "ehlül adl ve't-tevhid" olarak isimlendiren Mu'tezile'ye göre Allah, iyi ya da kötü arasında onların iyi ya da kötü oluşuna göre ayırım yapmaktadır. İyilik ya da kötülük varlıkların özlerinde bulunur ve bunların bir kısmı akılla da bilinebilir. ${ }^{32}$

Mu'tezile'ye göre fiiller, sonucunda ortaya çıkan fayda ve zarara göre değerlendirilmelidir ki her fiilin bir amacı vardır. Onlara göre Allah'ın fiillerinde amaç olmadığını düşünmek abesle iştigaldir ve O'nun kulları için aslahı gözetmediğini düşünmek, kullara zararı olabileceğini düşünmek O'nun zalim olduğunu ve adaletsiz olduğunu düşünmekle aynıdır. ${ }^{33}$

Fiilleri fayda ve zarar açısından ele alan Mu'tezile, iyi fiili fayda gözetilerek yapılan kötü fiili ise zarar doğuran şey olarak tanımlamakta ve buna bağlı olarak Allah'ın bütün fiillerinde iyi bir gayeyi gözettiğini bunun için O'nun bütün fiillerinin iyi olduğunu savunur. Bu iyi gaye de faydayı beraberinde getirdiğinden dolayı Allah'ın bu fiilleri Mu'tezile'ye göre kulları içindir. Mu'tezile'nin bu anlayışı "aslah" anlayışını doğurmaktadır. Şer problemini de "aslah" anlayışından dolayı Allah'a 19: 62.

31 Cihat Tunç, Kelam IIminin Tarihçesi ve Illk Kelam Okulları, (Kayseri: Netform Matbaacılık, 2001), 107.

32 Ömer Mahir Alper, İslam Felsefesinde Akıl-Vahiy Felsefe-Din İlişkisi, (İstanbul: Ayışığı Yayınları, 2000), 20.

33 Kazanç, "Tanrı ve Kötülük", 19. 
isnad etmeden Mu'tezile kulun fiillerinin yaratıcısı olduğunu savunarak çözmeye çalışır. ${ }^{34}$ Allah'ın adil olduğunu, O'nun asla zulüm yapmadığını ve O'nun yalnızca iyiliği değil aynı zamanda aslahı kulları için yaratmasında mecbur olduğunu savunan Mu'tezile, aslında bir yandan ilahi adaleti savunurken kötülüğü de kullara atfederek diğer yandan ilahi kudreti sınırlandırmıştır. ${ }^{35}$

Mu'tezilîler insanın eylemlerini bizzat kendi hür iradesiyle yaptığını savunur ve Allah'ın bu noktada yani insanların eylemlerinde herhangi bir müdahalesi düşünülemez. ${ }^{36}$ Mu'tezile şer veya kötülük durumlarını bu şekilde insanla ilişkilendirir. Allah hayır irade eder ve yaratır ise de şerleri ve kötülükleri irade etmez ve yaratmaz. ${ }^{37}$

Mu'tezile kötülüklerin Allah'a nispet edilemeyeceğini söylerken, bela ve felaketlerin, acı ve elemlerin O'na nispet edilemeyeceğini kastetmemekte bilakis sadece bunların ilahi fiillerle ilintili oldukları durumlarda kötülük olarak nitelendirilemeyeceğini vurgulamaktadır. ${ }^{38}$

Tabiattaki felaketler hususunda Mu'tezilî bakış açısı, bunların mecazî kötülük olduğu aslen ise iyi ve hayır olan şeylerdir ki Allah bu kötülüklere kullarının sabrına karşılık cenneti vermekte, ayrıca kullarına bu tür felaketlerle kıyametin azabını dünyada iken tattırmaktadır. Mu'tezilîler bu görüşlerinin temelini fiilin güzel veya çirkin olması açısından bakmadan fayda ve yarar açısından belirlerler ve onlara göre her güzel fiil faydalı, her çirkin fiil de zararlı değildir. ${ }^{39}$

Mu'tezilî kelamcıların metafiziksel kötülüklere şer dememesinin nedeni de Allah'ın varlık hakkında murad ettiği gaî eylemler dolayısıyladır. Zira onlara göre bir işe kötü diyebilmek için onun zulüm ya da abes olması gerekmektedir. Allah'tan kaynaklandığı bilinen hastalıklar, afetler veya şer olarak kabul edebileceğimiz her türlü kötü durumlar, ölüm sonrasında bedeli fazlasıyla ödenilecek bir durum dolayısıyla da eskatolojik bir gayeye yönelmiş olduğuna göre kötülük olmaktan çıkarlar. ${ }^{40}$

Avni IIlhan, "Aslah", Türkiye Diyanet Vakfı Islam Ansiklopedisi, (İstanbul:TDV, 1991), 3: 495.

Ormsby, Ilahi Adalet Sorunu, 32.

Kazanç, "Tanrı ve Kötülük", 26.

Emrullah Yüksel, "Illahi Fiillerde Hikmet", Atatürk Üniversitesi Ilahiyat Fakültesi Dergisi, 8 (1988): 64. Rafiz Manafov, "Meşşai Felsefe ve Kelam Düşüncesinde Adl-i Illahi Meselesi", Selçuk Üniversitesi Illahiyat Fakültesi Dergisi, 28 (2009): 114.

Özdemir, Kötülük Problemi, s. 66.

Manafov, "Adl-i Illahi Meselesi", 114. 
Sonuç olarak Mu'tezile'nin şer problemine yaklaşımı insan iradesinin özgürlüğü nedeniyle kötüye kullanılması, tabi kötülük olarak bilinen şerlerin gai nedenlerle "iyi" oluşu, hayvan ve çocuk acılarının bedeli ödenilmekle aklanabileceği noktasında odaklanmaktadır. ${ }^{41}$

Mu'tezile'nin kötülük probleminin ortaya çıkarmış olduğu sorunlara genel olarak vermiş olduğu cevaplar bu şekildedir. Şimdi Eş'arîlerin bu hususta vermiş olduğu cevapları genel itibari ile sunmaya çalışacağız.

Eş'arîler güzellik ve çirkinliğin izafi olduğunu savunurlar ve bunların fiilin aslında bulunmadığını, dinin emir ve yasakları ile anlaşılacağını ileri sürerler. Onlar iyilik ve kötülük meselelerini Allah'ın dilediğini yapan fail-i muhtar olması düşüncesi ile açıklamaktadırlar. ${ }^{42}$ Ayrıca Eş'arîler daha literal bir ilahi kudret anlayışına dönerken adalet hakkında daha büyük problemlerin ortaya çıkma riskini bile göze aldılar. Eş'arîlik iyilik ve kötülüğün objektif bir varlığının temeli olduğunu tamamen inkâr ederek iyilik ve kötülüğün ilahi hükümle belirlendiğini savunurlar. ${ }^{43}$ Eş'arî, iyilik ve kötülüğün fail-i muhtar olan Allah'ın takdir ve kazasıyla gerçekleştiğini; bizim de hayır ve şerriyle kader ve kazaya iman ettiğimizi ifade etmektedir. Çünkü O’na göre kul Allah'ın dilemesi dışında kendisi için ne iyiye ne de kötüye güç yetirebilir. ${ }^{44}$

Eş'arîlerdeki adalet anlayışı ise Allah'ın kendi mülkünde dilediği gibi tasarrufta bulunmasıdır ve onlara göre Allah'ın fiillerinin ne kendine yönelik ne de insanlara yönelik maksat ve maslahat yönü bulunmamaktadır. Çünkü Allah bu şekilde eylemde bulunursa bir sebebe bağlanmış olur ki bu da bir eksikliktir. Amaç, maksat ve maslahat fiillerin sonucunda ortaya çıkar. ${ }^{45}$ Eş'arîler bundan dolayı kötülüğün Allah tarafından yaratılmasının zulüm olarak ele alınamayacağını fiillerin Allah' a nispetle değil insanlara nispetle değer kazandığını savunur. ${ }^{46}$

Eş'arîler, Tanrı-evren ilişkisi hususunda ise Allah evren için daha mükemmeli olabilecek iken onu o şekilde yaratmasaydı O'na acizlik ve noksanlık ilişirdi diyerek, onlara göre Allah bunlardan münezzeh olduğu için O’nun yarattığı her şey tam 
ve mükemmeldir; var olan kötülük türlerinin hiçbirisi zulüm değildir anlayışını benimsemişlerdir. ${ }^{47}$

Genel olarak Eş'arîlerin vermiş olduğu cevapları kötülük ve iyiliğin yaratma açısından Allah'a nispet edilmesi gerektiği ve bundan dolayı mülkün sahibi olanın zalim olarak nitelendirilemeyeceği, insanın fiillerinden sorumlu olduğu, evrenin yaratılabilecek en mükemmel şekliyle yaratıldığı ve iyi-kötü hususunda hüküm merciinin vahiy olduğu şeklinde özetleyebiliriz.

Konunun kelami açıdan önemi ve problemin tam olarak ortaya koyulabilmesi için kötülük probleminin ortaya çıkardığı sorulara Maturidilerin vermiş olduğu cevaplar bağlamında da bakmak gerekmektedir.

Maturidi Kitabu't Tevhid isimli eserinde zikrettiği üzere adalet bağlamında hikmet kavramını Allah için zorunlu görmemektedir. Maturidi hikmet ve adaletin husün, zulüm ve sefihliğin kubuh olarak görülmesi gerektiğinin sabit olduğunu fakat bazı durumlarda hikmet ve sefihliğin, zulüm ile adaletin beraber ortaya çıkabileceğini ifade eder. Ona göre yaşadığımız âlemde insan hikmetli bir işi veya zıddını tercih edebiliyorsa, Allah da hikmetin zıddına kâdirdir. Fakat Maturidi, hikmete uygun hareket etmemenin sebebinin cehalet veya ihtiyaçtan kaynaklandığını ifade ederek bu sıfatlardan münezzeh olan Allah'a zulüm ve sefihlik vasıflarının ilhak edilmesinin batıl olacağını ve bundan dolayı Allah'ın hikmetin dışına çıkmayacağını savunur. Maturidi, insan fiillerinin iyi ve kötü olarak vasıflandırılmasını Allah’ın bu fiilleri murat etmesine değil insanın fiillere olan ahlaki yaklaşımıyla ilişkilendirmektedir. ${ }^{48}$ Maturidi'ye göre bir fiilin insana nispeti başka bir yönden Allah'a nispetine engel değildir ki fiilleri oldukları gibi yaratması Allah'a, fiillerin kesbedilmesi yönünden insana aittir. Maturidi, fiillerin yalnızca tek yönlü olarak düşünülmesi halinde yani ya insana ya da Allah'a nisbeti durumunda sorumluluk ve Allah'ın kendisini Kuran'da sıfatlandırdığı vasıflar açısından sıkıntılar ortaya çıkacağını ifade eder. ${ }^{49}$

Bir fiilde yaratmak ve yapmak (kesb) olmak üzere iki yön bulunmaktadır ki yaratılış yönünden fiil Allah'a kesb yönünden insana atfedilir. Maturidiler, insanların

48 Mâtürîdî, Kitâbu't-Tevhid, haz. Bekir Topaloğlu, Muhammed Aruçi, (Ankara: İSAM, 2005), 346; Çağrıcı, İslam Düşüncesinde Ahlak, 107. 
fiillerinin yaratılışını Allah'a; iman-küfür, hayır-şer vb. vasıflarını insanın kudretine nispet ederler. Maturidi akımın temel görüşlerini aldığı Ebu Hanife, insanın her yönüyle yaratılmış bir varlık olmasını, fiillerinin de yaratılmış olmasının gerektiğinin delili olarak ileri sürer. ${ }^{50}$ Aliyyu'l Karî de Şerhu Fıkhil Ekber isimli eserinde kötülüklerin meydana gelişini Allah'ın rızasına değil kaza ve iradesine bağlar ki rıza güzel işlere, irade ve takdir kulların iyi ve kötü bütün işlerine taalluk eder. ${ }^{51}$

\section{3. İslam Filozoflarında Kötülük Problemi}

İslam filozoflarında kötülük problemine verilen cevaplar hususunda bu konunun ayrı bir çalışma olacak kadar kapsamlı olmasından dolayı burada Meşşai geleneğin öncüleri olarak sayabileceğimiz el-Muallimu's-Sani olarak anılan Farabi ve İbn Sina ile Aristo'nun kabul görmüş en önemli şarihi İbn Rüşd'ün bu probleme yaklaşımlarını açıklayacağız.

Farabi, sudur teorisinden hareketle tikellerin basit ve tek olan Tanrı tarafından yaratıldığını; bu yaratılan şeylerin ise bir kısmının akli niteliğe bir kısmının duyusal niteliğe sahip olduğunu savunur. Ona göre aklın ulvi âlemden getirdiği her şey yüce ve faziletlidir, kötülük ise aklın hissi olandan getirdiği şeyden kaynaklanmaktadır. ${ }^{52}$ Varlıkların, Vacibu'l Vücud'dan feyezan ederek meydana gelmeleri sonucunda hiçbirinde zulüm, bozukluk, uyuşmazlık, kötü nizam vb. olumsuz diyebileceğimiz kötülüğü içinde barındıran hiçbir şey bulunmamaktadır. Mükemmel olarak tasarlanan bu evrenin nizamının kaynağı sırf iyi olan Vacibu'l Vücud olan Tanrı olduğundan dolayı salt iyi olandan kötü bir nizamın veya kötülüğün sadır olması düşünülemez. Sudur içerisindeki yaratılış düzeni ve nizamı Tanrı́nın fiil ve sıfatları ile alakalı olduğundan dolayı da kötü bir fiili Tanrı'ya atfetmek de muhal bir durumdur. ${ }^{53}$

Farabi, "âlemin müdebbiri" olan Tanrı́nın âlemde birlik ve nizamı her varlıkta aynı gaye üzerine tek bir vücut gibi hareket edecek yatkınlıklar yarattığını ifade eder ve âlemde kötülüğün var olmasını maddenin ilahi nizamı tam olarak kabul edemeyişinden kaynaklandığını savunur. Filozofa göre âlemde aslolan hayır ve nizamdır, kötülük ise arızi olarak ortaya çıkmaktadır ki burada bahsolunan tabii kö- 
tülük türüdür. Sudur nazariyesi temeline dayanarak metafizik kötülüğe karşı bir cevap ortaya koyan Farabi, ahlaki kötülüğü de tabii kötülük ile ilişkilendirmekte yani insan bedenine-maddeye dayanarak açıklamaktadır. ${ }^{54}$

Kötülük hayrın eksikliğidir ve varlık hiyerarşisinde yukarı gidildikçe hayır artar, aşağı inildikçe de Mutlak Hayır olan Zorunlu varlıktan uzaklaşıldığı için kemal azalır. Bu ontolojik düzende kemal yönünden en eksik olan şey maddedir. Kötülüğün bir açıklaması bu olmakla beraber bir diğer açıklaması da onun arızi bir şey olduğu ve bize göre kötülük olanın aslında çok hayır için gerekli olduğudur. ${ }^{55}$

Farabi'ye göre kötülük bir noksanlık, yokluk ve zayıflık sebebiyle ortaya çıktığından yalnızca ay altı âlemde bulunmaktadır ve ay altı âlemde bulunmasının yegâne sebebi de heyuladır ki bir hatanın ona dâhil olmasından kötülük meydana gelmektedir. ${ }^{56}$

Farabi, insani şerlerden bahsederek bunların insanın yaratılış gayesini engelleyen melekeler ve iradi fiillerden kaynaklandığını ve insanın gerçek mutluluğu elde etmesinde bunların engel teşkil ettiğini ifade etmektedir. Adalet temini için suçlulara verilen cezaların kötü olmadığını savunan filozof, bu gibi şerlerin iyilik için araç olduklarını ifade eder. ${ }^{57}$

Farabi, her olup bitenin Allah'ın kaza ve kaderi ile gerçekleştiğini savunarak kötülüğü de buna bağlar. Ona göre kötülükler değişen sufli âlemde gerçekleşen izafi olarak bakabileceğimiz bir vasfa sahiptir ki iyiliklerin çok ve sürekli olmasının nedeni kötülük ile ilişkilidir. Farabi, iyiliğin ön şartı olan az kötülükten kaçınıldığında daha büyük bir kötülük yapılmış olacağını ifade eder. ${ }^{58}$

İbn Sina'ya göre Zorunlu Varlık sırf iyiliktir; iyilik ise her şeyin arzuladığı şeydir. Filozofa göre iyilik herkesin arzuladığı bir şey olduğu için ya varlıktır ya da varlığın yetkinliğidir, yokluk ise bunun tam zıddıdır. İbn Sina, Zorunlu Varlık'ın sırf iyilik olduğunu ifade eder, mümkün varlıkları ise yokluğu muhtemel olmasından ve kötülük ve eksiklikten uzak olamayacağından dolayı sırf iyilik olarak vasıflandırmaz..$^{59}$ Ayrıca filozof, sırf iyilik olan Tanrı anlayışı gereği âlemde de buradan feye- 
zan eden bir iyilik düzeninin bulunduğunu ifade eder. Bu iyilik ve adalet düzeni filozofa göre âlemdeki bütün varlıklarda görülebilir. ${ }^{60}$

İbn Sina'nın sudur teorisi ile ortaya koyduğu varlık hiyerarşisi ve evren anlayışı, bunların Evvel ${ }^{61}$ olanın bilgisiyle feyezan ettiğinden ve O'nun sırf iyilik olmasından dolayı Tanrı'nın hikmetinin bir sonucu olarak mümkün âlemin en yetkin biçimiyle var olduğunu gösterir. Yani filozofa göre inayet evrensel düzenin Tanrı́nın ilminde içkin olmasıdır ki bu da beraberinde âlemin en güzel biçimde yaratıldığının göstergesidir.62

İbn Sina'ya göre kötülük iyilik sınırları içinde olduğundan dolayı ikisi farklı tabiata sahip değildir ve Zorunlu Varlık bu şekilde kötülükten soyutlanır, iyilik ve hayra fail olarak engel olmaz. Ona göre evrende var olan kötülük münfail olan varlıktaki istidat eksikliğinden kaynaklanmaktadır. Örneğin; ateşin asıl yaratılışı bir fayda içindir, fakat bazen arızi ve cüzi zararı ortaya çıkabilir. Bundan dolayı ateşin çok faydasını bırakıp da az olan arızi zararına bakarak onu yok etmek saçmadır. ${ }^{63}$

İbn Sina'ya göre evrende iyilik ve kötülük bir arada bulunmasaydı, evrenin nizamı tam olmazdı; sadece iyilik ya da sadece kötülük bulunsaydı bu âlem başka bir âlem olurdu. ${ }^{64}$

İbn Sina Kader Sırrına Dair risalesinde kaderin sırrını kâinat düzeni, ceza ve mükâfatın olduğunu bildiren haberler ve ruhların haşri öncüllerine dayandırarak ortaya koymaya çalışmaktadır. Filozofun birinci öncülü olan kâinat düzeni, süfli ve ulvi tüm parçalarıyla müdebbir olan Allah'ın bilmesi, onları yaratması ve varlıklarını irade etmesinden müstağni olamayacak şekilde bir düzendir. Var olan âlem İbn Sina'ya göre düzeni tam olan gayrısı düşünülemeyecek bir âlemdir ve iyiliği de kötülüğü de içinde bulundurarak meydana gelmiştir. Ona göre eğer bu âlemde sırf iyilik olsaydı veya sırf kötülük olsaydı bu âlem farklı bir âlem olurdu. Filozof ikinci öncülü olan mükâfat ve ceza hususunda mükâfatı ruhun olgunluğu Dergisi, 13 (2010): 269.

61 Evvel; Meşşai düşüncede ortaya koyulan sudûr nazariyesinde "Bir'den yalnızca Bir çıkar" önermesi bağlamında Tanrı́nın kendini düşünmesi ve bilmesi sonucunda ortaya çıkan manevi cevhere verilen isimdir yani ilk akıldır. Bkz. Mahmut Kaya, "Sudûr", Türkiye Diyanet Vakfı Islam Ansiklopedisi, (İstanbul: TDV, 2009), 37: 467.

62 İbn Sina, Metafizik, 160.; Necip Taylan, Düşünce Tarihinde Tanrı Sorunu, (İstanbul: Ayışığı Yayınları, 1998), 155.

63 Taylan, Tanrı Sorunu, 155.

64 Taylan, Tanrı Sorunu, 157. 
derecesinde lezzet almasl; cezayı ise Allah'tan uzaklaştığı nispette ruhun noksan kalması olarak tanımlamaktadır. İbn Sina üçüncü öncülü olan haşri ise insan ruhunun kendi âlemine dönmesi olarak tanımlamaktadır. ${ }^{65}$

Bu öncüllerden yola çıkan İbn Sina, Allah'ın emirleri, yükümlü olanın fiilleri işlemesinin, yasakları da sakınanın sakınmasının bir sebebidir. Ayrıca filozof Aristo'nun "âlemin yaratılmasındaki maksat iyiliklerdir, kötülük ise yokluktur" ve Eflatun'un "iyilik de kötülük de amaçlanmış, irade edilmiştir" görüşlerinden yola çıkarak Allah'ın emirleri ve yasaklarının bunlara uyacak insanlar için teşvik ve sakındırma amaçlı olduğunu savunmuştur. İbn Sina, Allah'ın kötülüklerden bir kısmını bu şekilde insanlardan uzaklaştıııldı̆ını ifade eder. İbn Sina, insanların aklın veya şeriatın gerektirdiği şekilde hareket etmesinin âlemin düzeni açısından önemli olduğunu ve eğer insanlar bu ikisinden hiçbirine bağımlı olmaz ise dünya düzeninin bozulacağını savunur. ${ }^{66}$

İbn Sina kötülüğü tabii, ahlaki ve metafizik olarak ele almıştır. Ona göre var olan her şey ya sırf iyidir ya da sırf kötüdür ya bir yönden iyidir ya da bir yönden kötüdür; bu durumda ya iyilik üstündür ya da ikisi eşittir. Bu bağlamda Yüce Tanrı ve O'na yakın akıllar sırf iyidir, mutlak anlamdaki kötülüğün varlığa çıkması ilahi hikmete aykırı düştüğü için imkânsızdır. Varlıkta şerrin hayra üstün gelmesi yani az iyilik için çok kötülüğü kabullenmek de ilahi hikmete aykırıdır ve bundan dolayı hayrın şerre üstün gelmesi ilahi hikmete en uygun olan durumdur. ${ }^{67}$

İbn Sina iyilik ve kötülüğü ortaya çıkmaları bakımından sırf iyi ya da sırf kötü, bir yönden iyi ya da bir yandan kötü veya iyilik kötülüğe üstün ya da eşit olarak tasnife etmektedir. Bu tasnife bağlı olarak Tanrı sırf iyidir, mutlak anlamdaki kötülükler ilahi hikmete uygun olmadığından imkânsızdır, kötülüğün iyiliğe üstün gelmesi veya eşit olması az bir iyiliği çok kötülüğü kabullenmek olduğundan imkânsızdır ve sonuç olarak iyiliğin kötülüğe üstün bulunması evrende çok olduğundan ilahi hikmete uygun olan da budur. ${ }^{68}$

İbn Sina kötülüğün çeşitlerini zayıflık, cehalet gibi sebebin yoksunluğuna ve elem, keder gibi sebebin idrakine bağlı olarak ele almaktadır. İbn Sina, güneşin ışığın2004), 31-32.

66 Ibn Sina, Risaleler, 32-33.

67 İbn Sina, Risaleler, 62; Taylan, Din Felsefeleri, 202.

68 Taylan, Tanrı Sorunu, 156. 
dan beslenen bir varlığın bulutun engellemesi sonucunda bu ışıktan yararlanamamasını örnek gösterir ki ona göre bu varlık bulutun engel teşkil ettiğini bazen idrak edebilir bazen de idrak edemeyebilir. Filozof idrak eden olduğu zaman bu varlığın eza duymayacağını belirtir. İbn Sina böyle bir durumda kötülüğün kendisinde değil kıyasla olduğunu ifade ederek sıcaklığın elem duyana kıyasla kötü olduğunu fakat başka bir kıyasla kötü olmadığı durumların da var olduğunu ileri sürer. Filozof kötülüğü mutlak ve bilaraz olarak tasnif etmekte; mutlak kötülüğü bir şeyin doğasında ve türünde gerekli olan yetkinliklerin yokluğu, bilaraz kötülüğü ise hak edenden yetkinliğin engellenmesi olarak tanımlamaktadır. ${ }^{69}$

İbn Sina, varlıkların mümkün olan en mükemmel şekilde var olduklarını savunur. Filozofa göre bazı varlıklarda görülen kötülükler hikmetten kaynaklanan ve düzeni tamamlayan unsurlardır. İbn Sina kötülüklerin şahıslara, zamanlara ve yapılara izafe edilmesi gerektiğini ifade eder ki bir türün bir ferdinde ortaya çıkan kötülük ona göre eksikliği kabullenenin yetkinliğinden kaynaklanmaktadır. ${ }^{70}$

Filozof, sudur teorisi bağlamında Zorunlu Varlık'tan uzaklaşıldıkça kemaliyetin azalacağını ve en uzak olanın madde olduğu için şerrin en fazla olduğu yerin ay-altı âlem olduğunu savunmuştur. Bu görüşleri selefi olan Farabi'nin kötülük problemi hakkında söylemiş oldukları ile benzerlik arz etmektedir..11

İbn Sina, eşyadaki kötülüğün varlığını iyilik için gerekli görmekte ve bazı durumlarda bulunabilecek iyiliğin bir kötülüğün gerçekleşmesi mümkün olduktan sonra ortaya çıktığını ifade etmektedir. Filozof, ender bir kötülük nedeniyle ortaya çıkacak genel bir iyiliği terk etmenin, maddenin doğasında bulunabilecek şeyin yokluğunun iki yokluk olmasının tek bir yokluk olmasından daha kötü bir durum olacağına binaen daha büyük bir kötülük olacağını savunur. İbn Sina, Ilk Yöneticinin kötülükten arınmış sırf iyiliği var etmesinin mümkünlüğünü bu varlık tarzı için düşünülemeyeceğini ve bu varlık tarzının olmamasının olmasından daha büyük bir kötülük olacağını savunmaktadır. Ayrıca ona göre var olan bu düzen imkân dâhilindeki en iyisidir ve kötülüğün varlığının O'ndan feyezan etmesi zorunludur. ${ }^{72}$ İbn Sina, Tanrı́nın bilmesi ile insanın bilmesini birbirinden ayırt ederek Tanrı'nın külli olarak bildiğini insanların ise cüzi bilgisi ile buna vakıf olamayacağını ifade 
ederek bundan dolayı şer ve hayrın arkasındaki hikmetin insan tarafından bilinemeyeceğini belirtir. ${ }^{73}$

İbn Sina, yerilen fiillerin ve bu fiillerin ilkeleri olan huyların kötülük olduğunu belirterek huyların kötü olmasının sebebi olarak yerilen fiillerin onlardan çıkmasını gösterir. Ona göre "kötü" denilen fiillerin tamamı kendi fail sebebine kıyasla yetkinliktir ve kötü denilen fiil kabul edene veya maddedeki fiilini engelleyen başka bir faile kıyasla kötülük olarak kabul edilebilir. İbn Sina burada gazap gücü örneğini vererek, zulmün gazap gücünün yetkinliğinden ortaya çıktığını ve galip gelmeye kıyasla duruma göre kötülük veya iyilik olarak nitelendirilebileceğini ifade etmektedir. Ona göre natık nefsin yetkinliği de zulüm gibi kötü vasıfları yenmekle gerçekleşecektir ve natık nefs bu gayeye ulaşamaz ise bu durum ona kıyasla kötülük olacaktır. ${ }^{74}$

İbn Sina kötülüklerin çoğunlukta olduğunu savunanlara çok olmak ile çoğunluk arasında fark olduğunu vurgulayarak kötülüğün çok olduğunu, çoğunlukta olmadığını cevaben verir. ${ }^{75}$ Ona göre kötülüğün çok olması ile çoğunlukta olması farklı şeylerdir. Bizim dünyada gördüğümüz birinci türden yetkinliklerin eksikliğinden kaynaklanan kötülüğün çok olduğunu savunan İbn Sina, ikinci türden yetkinliklerin ise çoğunlukta olduğunu ifade eder. Ancak filozofa göre ikinci tür yetkinlikler yani insan için geometri veya matematik bilmemek türün devamı için gerekli olmadığından tam anlamıyla kötülük olarak adlandırılamaz. Çünkü filozofa göre ikincil tür yetkinlikler, ilk yetkinliklere ve onlara bağlı olarak ortaya çıkan yararı açık olan yetkinliklere zarar vermezler. Filozof ikincil tür yetkinliklerin eksikliğinden ortaya çıkan kötülüklerin, failin fiili olmadığını yalnızca failin istidatlı olmamasından veya kabule hareket etmemesinden kaynaklandığını belirtir. Ona göre bu sebeplerden dolayı bu "ilave" kabilinden iyiliklerin yokluğu olan ikincil tür yetkinlik eksikliğinden kaynaklanan kötülükler çok değil çoğunluktadır. ${ }^{76}$

İbn Rüşd Tehafüt-ü Tehafüt isimli eserinde antik filozofların "Bir'den ancak Bir çıkar" görüşünü benimsediklerini ve ilk ilkelerin biri iyilik diğeri kötülük iki kısımdan oluştuğunu savunduklarını ifade eder. Ona göre daha sonra filozoflar, bütün varlıkları inceleyip evrendeki düzenin kentteki düzeni sağlayan bir yöneticinin olması gibi evrenin de bir müdebbiri olması gerektiği sonucuna ulaşarak iyiliğin 
bütün varlıklarda yerleşik ve yaratılış gayeleri olduğu, kötülüğün ise ilintisel olduğu kanısına vardılar. İbn Rüşd, Kur'ân-ı Kerim'de bu görüşü destekleyen "Eğer yerde ve göklerde Allah'tan başka tanrılar bulunsaydı, her ikisi de bozulup gitmişti" (Enbiyâ, 22) ayetinin bulunduğunu ve filozofların bu görüşlerine bağlı kalarak kötülüklerin erdemli yöneticilerin koymuş oldukları cezaların ilk amacının iyilik olması gibi bazı durumlarda iyiliğin kötülük ile beraber ortaya çıktığını savunmaktadır. Ayrıca ona göre, antik filozofların savunduğu gibi, azıcık kötülük var oldu diye büyük iyiliği terk etmek abes bir durumdur. ${ }^{77}$

İbn Rüşd, evrende kötülüğün var olmasının sebebini hikmet temelli açıklamaktadır: bu evren ya yaratılacaktı ya da yaratılmayacaktı, yaratılmasaydı az şerden dolayı çok hayır terk edilmiş olacak ve daha büyük bir kötülük meydana gelmiş olacaktı; bundan dolayı az şerli olan evrenin yaratılması daha hayırlıdır. Bununla beraber İbn Rüşd, Allah'ın meleklere insanı halife olarak yaratacağını haber verdiği zaman meleklerin vermiş oldukları cevabın şerrin hikmetten oluşunu bilemediklerinden kaynaklandığını ifade eder. Ayrıca filozof, Kuran'da anlatılan bu olayın bir şeyin varlığında hayır ve şer ciheti bulunup, hayrın ağır basması halinde hikmet gereği onun var olmasının gerekli olduğunu gösterdiği şeklinde yorumlamaktadır. ${ }^{78}$

İbn Rüşd'e göre bizlerde bulunan akıl varlıklardaki dizgeliliğin ve düzenin tamamını algılama noktasında eksik kalmaktadır. ${ }^{79}$

İbn Rüşd kötülük problemini cevr ve tadil başlığı altında ele almaktadır ve problemi, bu kavramların Allah'a isnat edilip edilemeyeceği, bir şeyin iyi veya kötü oluşunu belirleyen ölçütün akıl mı yoksa şeriat mı olduğu hususları bağlamında ortaya koyarak çözmeye çalışmaktadır. ${ }^{80}$ Filozof, Tanrı́nın "şüphesiz Allah insanlara hiçbir şekilde zulmetmez; fakat insanlar kendilerine zulmederler" (Yûnus, 44) ayetine istinaden fiillerinin adil olması gerektiğini savunur. Buradan hareketle ve de müşahede yoluyla âlemde şerrin var olduğunu belirten filozof, âlemin mümkün olmayan yegâne âlem olduğunu benimser ve ona göre tersi olması ilahi hikmetin olmamasına yani zulme yol açar. Şer konusuna dogmatik yaklaşımı bu şekilde olan filozofun rasyonel yaklaşımı ise yararlı gıdaların nasıl hasta bedene do Siyah Klasik Yayınları, 2006), 166. (İstanbul: Dergâh Yayınları, 1985), 343.

80 Hüseyin Sarıoğlu, İbn Rüşd Felsefesi, (İstanbul: Klasik Yayınları, 2003), 264-265. 
fayda vermiyorsa doğru bilginin, iyi öğütün bazı kimselere yarar vermeyeceği şeklindedir. Yani ona göre âlemde hayır şerre göre üstündür ve kötülük arızi bir durum olup fertlere ilişen bir durumdan ibarettir. ${ }^{81}$

İbn Rüşd, hayrın da şerrin de Allah tarafından yaratıldığını ve dalalete sevk eden sebeplerin de O'nun tarafından yaratıldığını ifade ederek, bunun sebebini hayır için şerrin gerekli olduğunu savunarak açıklamıştır. Filozofa göre Allah hayrı hayrın bizzat kendisi için, şerri de hayır için vesile olması amacıyla yaratmıştır ki bu da O'nun adaletinin bir eseridir. Bu noktada İbn Rüşd, ateş örneğini vererek, ateşin sayesinde var olan mevcudat için gerekli olduğunu ve bazı arızi surette ondan şer ortaya çıkabileceğini söylemektedir. Bundan dolayı ateşin yaratılış gayesi hayır içindir, arızi durumda ortaya çıkan şerden dolayı yaratılmamış olması daha büyük bir şer olacağından dolayı var olması daha hayırlıdır.

İbn Rüşd, "Allah yaptığından mesul değildir, ama insanlar mesuldurler" (Enbiyâ, 23) ayeti kerimesinden yola çıkarak Allah'ın bir işi kendisine vacip olduğundan dolayı yapmadığının ve insanın yaptığı şeyi bizzat kendisi için yaptığının anlaşılması gerektiğini savunmaktadır. Ona göre bir fiili yapmaya mecbur olan varlık o fiile muhtaçtır ve bu fiille noksanını kemale erdiriyor demektir ki Allah bu durumlardan münezzehtir. Filozof, Allah'a ve insana nispet edilen adalet arasındaki farkın muhtaçlık ve noksanlık boyutlarıyla ele alındığı zaman anlaşılabileceğini ifade eder. İnsan bizatihi hayırlı olan sonuca ulaşmak için adalete riayet eder ki Allah kesinlikle bundan münezzehtir.82

Genel olarak İslam filozofları, sudur teorisi temelli evren tasavvurları bağlamında kötülüğün kaynağını ve meydana gelmesinin sebebini madde ile ilişkilendirerek açıklamaktadırlar. Yaratılmış olan bütün varlıkların kemal derecelerine bakıldığı zaman, bu derecelerin bir olan Vacibu'I Vücud'dan varlığın uzaklaşması ile doğru orantılı bir şekilde azaldığı inancına sahip filozoflar, bütün kötülüklerin kevn ve fesad âlemi denilen maddi dünyada gerçekleşmekte olduğu düşüncesini genel olarak benimsemiş ve savunmuşlardır. Kısaca, teosofik bir yapıya sahip olduğu genel görüşle kabul edilen İşrakî düşüncenin, İslam filozofları özellikle Meşşaî filozoflar tarafından savunulan sudur teorisi ile belirli açılardan benzerlik arz eden nur hiyerarşisi anlayışı bağlamında birbirlerine yakın durduklarını ifade edebiliriz. Kötülük problemine verilen cevaplardaki karşılaştırmayı İ̧rakî teodiseyi açıkladıktan sonra sonuç bölümünde yapmak yerinde olacaktır. 


\section{4. İşrakî Teodise}

Sühreverdî ve takipçileri tarafından oluşturulan İşrakî düşünce sistemi "nur" kavramı üzerine bina edilmiştir. Bundan dolayı bu kavram bu düşünce sisteminin içerisinde her şeyin temelini oluşturmaktadır. İ̧rakî evren, insan ve Tanrı tasavvurları nur ekseninde açıklanmış ve bunlarla ilgili ortaya çıkan problemler de aynı şekilde bu kavram etrafında bertaraf edilmeye çalışıımıştır. Metafizik, fiziki ve ahlakî kötülüklere karşı da Işrakîler tarafından verilen cevapları sudur teorisine belli açılardan benzeyen Nuru'l Envar'dan yansıyan nurların durumlarını göz önünde bulundurarak değerlendirmek gerekir.

Sühreverdî şerrin zatının olmadığını aksine zatın veya zatın kemalinin yokluk hali olduğunu ve bir şeyin yokluğuna bağlı olarak bulunduğunu savunur. Ona göre şayet şer mevcut bir şey olsaydı bir şeyden diğerine geçmesi gerekirdi. Sühreverdî, bir eldeki parmakların sayısının fazla olması durumunun elin yaratılmış olan güzellik heyetini batıl kılacağından dolayı bu halin şer olduğunu savunur. ${ }^{83}$ Ona göre şer var olsaydı, şer ya kendinden ya da gayrından dolayı var olurdu. Her iki durumun da olamayacağını savunan Sühreverdî, yokluğun yalnızca arazî olarak faile nispet edilebileceğini ve bundan dolayı da şerrin faile arazî olarak nispet edilebileceğini savunmaktadır. ${ }^{84}$

Şehrezurî de Sühreverdî gibi şerrin zatı olmadığını aksine şerrin yokluk hali, zatın yokluğu veya zatın kemalinin yokluğu düşüncesini savunmaktadır. Ona göre şer eğer var olan bir şey olsaydı kendiliğinden veya bir başkası için şer olması gerekirdi ki linefsihi şer olması caiz değildir. Öyle ki bir şeyin varlığı olarak bulunsaydı, kendisinin yokluğunu da gerektirirdi veya kemalatlarından bir şeyin eksikliğini gerektirirdi. Bir şeydeki kemalatlardan bazı şeylerin yokluğu olan şey zaten şerdir, bu yokluktur, onun kendisi değildir. Şer bizim farz ettiğimiz gibi kendisi için veya gayrı için var olan bir hal değildir diyen Şehrezurî şu şekilde kıyas olunması gerektiğini belirtir: "Şayet şer var olan bir durum olsaydı şer, gayr-i şer olurdu ki talî olan batıldır, bundan dolayı mukaddem de batılır". Ona göre talî olanın butlanı, onun takririni gerektirir. Şer yokluğun halidir yani zatın yokluğu veya zattaki kemalin yokluğudur. Filozof kötülüklerin dünyadaki halleri üzerine teemmül ve 
istikra edildiği zaman şer ismine ıtlak edilen her şeyi saf yokluk veya yokluğun sebebi olarak bulacağımızı açıklar. ${ }^{85}$

Şehrezurî bir başka eşyaya kemalatine erişmesinde mâni olan bir başka eşya, meyveyi ifsat eden soğuk, meyveyi çürüten sıcak, elbisenin kumaşının beyazlamasına mâni olan yağmur gibi ölüm, cehalet, fakirlik vb. kavramları saf olan yokluk olarak açıklar. Ona göre cimrilik, israf, sefihlik, korkaklık vb. kötü huylar ve zina, hırsızlık, gıybet, nemime, cevr ve zulüm gibi olan elemler, hüzünler, kederlerin ve diğerlerinin benzerleri yerilmiş filler nefislerin aklî olan kemalatlara ulaşmasına mâni olmaktadır. Bu sıfatların veya eşyaların her biri zatı sebebiyledir, şer değildirler. Şehrezurî soğuk ve sıcak fiillerinin cismanî kemalattan olduğunu ifade ederek bunların aslen şer olmadığını savunur. Şer, fasit olan meyvenin mizacından ve ona yapışık olan eşyanın yokluğundandır. Filozof aynı şekilde ahlakta bulunan şehvanî ve gazabî kuvvetlerden ortaya çıkan fiillerin de kemalattan olduğunu açıklayarak bunların şer olamayacağını savunur. Şehrezurî mezmum ahlakın ve fiillerin tam olarak bedenî ve diğer kuvvetlerden dolayı aciz olan nefsin zayıflığına nispetle şer olduklarını savunur. Bu bağlamda filozof, zinanın medenî siyasete nispetle; acılarda, hüzünlerde ve kederlerde olduğu gibi zulüm, mazluma nispetle şer olduğunu belirtir. Şehrezurî cumhurun da bu görüşe sahip olduğunu ifade ederek dünyada şer olarak isimlendirilen mevcut eşyanın hepsi tetkik edildiğinde şerrin bulunamayacağını aksine diğer işlere nispetle şer olduklarını savunur. ${ }^{86}$

Sühreverdi'ye göre şer Allah'tan sadır olmaz aksine Allah'ın yaratmış olduğu ilk nurun mümkün olan yönünden kaynaklanır. ${ }^{87}$ Ona göre Nuru'l Envar'a heyetlerin ve karanlık cihetlerin ilişmesi imkânsız olduğundan dolayı O'ndan kötülük sadır olmaz. Zatî olarak akıllardan da şerrin hâsıl olamayacağını ifade eden Şeyh'ül İşrak aksine hareketin ve karanlık akılların fakr yönüyle yani muhtaçlığından dolayı arazî olarak şerrin hâsıl olabileceğini savunur. ${ }^{88}$

Sühreverdî insanın dünyadaki eleminin kaynağının maddi âleme duyulan şevk ve iştiyak olduğunu ifade eder. Ona göre Allah'tan uzaklaştığı için insan nasıl 
elemlere maruz kalacaksa bu uzaklaşmanın elemi kütlesel ateşin yani cehennemin ateşinin şiddeti ile gerçekleşecektir. ${ }^{89}$

İşrakî düşünceye göre kötülük ve mutsuzluk, karanlıklar ve hissî âlemlerde hâsıl olur. Bu âlemlerde hâsıl olmasının sebebi kahir -yani akıllar-ve müdebbir -yani nefis- nurların muhtaçlıkları yönüyle ve âlemlerin hareketlerinden dolayıdır. Kötülük vasıtalarla hâsıl olur. Kahir ve müdebbir nurların muhtaçlığından hâsıl olan karanlık ve hareketlerin vasıtasıyla kötülük meydana gelir. ${ }^{90}$

İşrakî düşünceye göre şekavet ve şer hissî âlemde ve hareketlerin meydana getirdiği karanlık misal âleminde mevcut olmakla beraber müdebbir feleklerin nefisleri ve aklî kahir nurlardaki fakr (muhtaçlık) sebebiyle meydana gelen karanlıklar âleminde zulmet gereklidir. Müdebbir ve aklî nurlardaki muhtaçlık cihetiyle gerekli olan zulmet ve hareketten dolayı şer vasıtalarla lazım hale gelir. Nuru'l Envar için zulmanî cihetten imtina edilmesi gerekir ki bundan dolayı aslen şer O'ndan sadır olmaz. Mücerred akıllara gelince, şer zatî olarak onların zatından sadır olmaz. Fakat fakr (muhtaçlık) cihetiyle arazî olarak şerri gerektiren hareket ve zulmetin onda lazım olmasından dolayı şer sadır olur. Feleklerden sadır olan hareketlerdeki bu hal aslında saf bir hayırdır. Onlara göre hayır; kevn ve fesadın, büyümenin, doğmanın aslıdır ancak bazı yaratılanlarda ve fesad olmuş şeylerde bazen kötülük bulunabilir.91

İşrakîlerin genel kabulüne göre muhtaçlık ve karanlıklar maluller için zaruriyetten hâsıl olur ki engellenmesi zor mahiyetlerin hâsıl olması gibi bir şeyin yaratılması illet ile gerçekleşir. Bu illet onun mahiyeti için gereklidir ve onun yaratılması bir diğerine muhtaçlık yönüyledir ki bu muhtaçlık karanlıklardan kaynaklanmaktadır. Şer, maluller için meydana çıkar ve bundan soyutlamak imkânsızdır. Bunun örneği zatı ve mahiyeti için üçgenin üç açıdan soyutlanmasının imkânsız olması durumu gibidir. Şerre ihtiyaç olmadan malulun yaratılması durumu daha iyi bir durumdur ve varlık bu sayede şerden beri olurdu fakat bu durum imkânsızdır.92

Sühreverdî, Hikmetu'I-Işrâk, Mecmua-i Musannefât-ı Şeyhi'l-işrâk içinde tsh. Henry Corbin, (Tahran: Pejûheşgah-ı Ulum-u İnsani ve Motaleat-ı Ferhengi, 2001/1380), 2: 235; Kazerunî, Şerhu Hikmeti'l-Işrak-ı Sühreverdi, 495.

91 Şehrezurî, Şerhu Hikmeti'l Işrak, trc. Hasan Ziyai Terbeti, (Tahran: Müessese-i Mütalaat ve Tahkikat-ı Ferhengi, 1993), 558.

Kazerunî, Şerhu Hikmeti'l Iş̧rak-ı Sühreverdi, 496. 
Şehrezurîye göre şerlerin kaynağı imkân ve yokluktur ki şayet bu ikisi olmasa kötülük de var olmazdı. Zatında vacip olanın yarattıkları saf hayırdır, aslen onlarda şer yoktur. Daha önce de ifade ettiğimiz üzere şer yokluk veya yokluğa sebep olandır. Orada yokluk yoksa şer de yoktur. Her yönden bilfiil olan eşyada kötülük yoktur, kötülük eşyada ortaya çıkan kuvvetlerde vuku bulur. Şarî, kaderin sırrını zikretmemiştir. Avam, kaderi keşfederse Barî Tealanın hâşâ aczi noktasında vehme kapılabilirdi. Şayet Allah mümkün olan varlıkların gayrını yaratamaz denseydi ateşi sıcaklık olmadan yaratmaya güç yetiremeyeceği gibi diğerlerinde de aynı düşünce üzerinden insanlar O'nun acziyeti hususunda vehme kapılırdı..$^{93}$

Şehrezurî, şer ve mutsuzluğun Allah'ın ilk kazasının tafsilatı olan kaderinden sayılacağını ve bunların O'nun rızasına bağlı olarak kötülük olmaksızın çok iyiliğin hâsıl olmasının, hayır ve şerrin birbirinden ayrılmasının düşünülemeyeceğini savunur. ${ }^{94}$ Ona göre kevn ve fesad âleminde var olan şerler kader konusuna dâhildir ve kader, ilk kazanın tafsilidir ki bu tafsilatları tertib eden ilk külli hükümdür. Şehrezurî, Allah'ın her canlı için ölüm hükmünü koymasını ilk kaza; her canlı için belirli bir zaman, belirli bir yerde bir hastalık veya özel bir illetle ölüm olayını ise kader olarak açıklar ki bu ilk hükmün detayıdır. Ona göre bu kötülükler ilahi inayetin bilgisi ve rızası (çok hayrın gerekliliği için bir rızadır) ile gerçekleşir. ${ }^{95}$

İ̧rakîler varlık ve evren tasavvurunun kemâliyeti bağlamında varlığın bulunduğu hal üzerinden daha tam veya mükemmel olarak tasavvur olunamayacağını savunurlar. Onlara göre şüphesiz Hak olanın zatı, daha aşağı olanı ve mümkün olan şereflileri terk etmeyi gerektirmez. Aksine O'nun zatı şerefliyi ve sonra daha şerefli olanı lazım kılar. ${ }^{96}$ İsrakî üstün mümkünlük kaidesine göre şiddeti fazla olan nur, şiddeti daha eksik olandan etkilenmez. Allah Teâlâ cehalet, acziyet veya cimrilikten berî olduğundan dolayı O'nun Zatı şerefli olanı sonra daha şerefli olanı lazım kılar. ${ }^{97}$ Devvanî Şevakilu'l Hur fi Heyakilu'n Nur Li's Sühreverdî isimli eserinde Şeyhu'l İşrak olarak kabul edilen Sühreverdî'nin bu durumları kitaplarında zikrettiğini ifade eder. Sühreverdî̀ye göre daha aşağı olan var olduğunda ondan

96 Sühreverdî, Heyâkilu'n-nûr, takdim Ahmet Abdürrahim Sayih, Tevfik Ali Vehbe, (Kahire: Mektebetü's-Sekafeti'd-Diniyye, 2009), 142; Sühreverdî, Hikmetü'-Işrâk, 154.

97 Celaleddin ed-Devvani, Şevâkilü'l-hûr fi şerhi Heyâkili'n-nûr li's-Sühreverdi, thk. Muhammed Abdülhak, Muhammed Kokan, (Bağdat: Beytü'l-Verrak, 2010), 234. 
daha önce daha şerefli bir mümkün varlığın bulunması lazımdır. Daha aşağı olan bir vasıta yoluyla var olur ki bu vasıtanın ondan daha şerefli bir varlık olmaması mümkün değildir. Çünkü illet malulden daha üstündür. Vacip olandan daha şerefli olanın sudur etmesi mümkün değildir. Vasıtasız meydana gelme daha şerefli için geçerli bir durum olmakla birlikte birden çokluğun sadır olmasını lüzum eder ki bu durumda muhaldir. Çünkü bu durum malulden daha aşağı bir illeti yaratması durumunda daha aşağı olan için vasıtanın onu sınırlandırması durumunu gerektirir ki bu durumda Bir'den yalnızca Bir sadır olmaz. ${ }^{98}$ Ayrıca daha iyi bir evreni yaratmak Allah Teâlấya mümkün olsaydı ve daha iyisini yaratmanın imkân dâhilinde olduğunu bilmeseydi küllileri ve cüz'leri kuşatan ilmini nefyetmiş olurdu. Mümkün olduğunu bilseydi kudreti yetmeseydi, bütün varlığı kuşatan varlığına ters düşen bir durum meydana gelmiş olurdu. ${ }^{99}$

Nurun yansımasının, yansımasının yansımasından daha şerefli olması öğretisiyle İşrakîlerin vardığı sonuç varlığın daha mükemmel olarak tasavvur olunmasının muhal olduğudur. Bu muhallik hiçbir kadirin kudreti altında değildir. Bu hal nizamın ve âlemin en mümkün halidir ki burada bulunan afetlerin yani, hastalık ve kusurların erişemediği başka bir âlem mevcuttur. ${ }^{100}$ Devvanî hastalıkların ve afatların erişemediği bu âlemlerin felekler, misaller ve bunların üstünde bulunan nefisler ve akıllar âlemleri olduklarını açıklayarak bu âlemlere nefislerimizden tahire olanların ve hilkatlerinde bulunan reziletlerden arınanların ulaşacağını ifade eder. Temiz insanî nefisler tabiî kuvvetlerini kullanarak şevklerinin fazlalığından dolayı taallukları şiddetli olacak ve nuranî misalî bedenlerinin unsurî beden ile taalluklarını keserek bu âlemlere intikal edeceklerdir. Bu âlemin iştah açıcı yiyeceklerinin ve güzel kadınlarının suretlerini müşahede ederek lezzete erişeceklerdir. Bazen felekî kütlelerle taalluk ederek suretlerin temsillerini müşahede edeceklerdir. Bu müşahede esnasındaki suretlerin zararlardan arınmış menfi yönlerini elde edeceklerdir. ${ }^{101}$

İsrakîler çokluk bakımından şerrin hayırdan daha az olduğu görüşünü savunurlar. Onların nur temelli evren ve varlık tasavvuruna göre bu âlem felekler âlemine nispetle, felekler âlemi akıllar âlemine nispetle, akıllar âlemi de rububiyet âlemine nispetle daha aşağıdadır. Bundan dolayı bu âleme nispetle şerre asıl olarak iti- 
bar olunmaz. Ayrıca kevn ve fesad âlemi tamamen şer olsaydı varlığın tamamına nispetle yine az bir şey olurdu. Düzen ve selamet varlıkta daha üstündür; hastalık ve acı çoktur ancak sıhhat ve selamet daha fazladır. İşrakîler bu görüşlerinden hareketle hayrın âlemde galip olduğu şerrin ise nadir olduğunu savunarak zatî olarak gerçek maksudun hayır olduğunu ifade ederler. ${ }^{102}$ Şehrezurî şerrin kevn ve fesad âleminde zıtlıklar sebebiyle var olduğunu, yaratılan âleme nispetle şerrin canlılarda az olarak bulunduğu görüşünü fesadın varlığa nispetle daha aşağıda bulunması durumuyla destekler. Ona göre de canlılarda sıhhat ve selamet daha fazladır; şer olarak nitelenen zararlar canlılarda bazen meydana gelmektedir. ${ }^{103}$

Şehrezurî varlıkta hayrın galip geldiği ve şerrin bizatihi maksut edilmeyen az bir şey olduğu hususunda bazı hukemanın şerrin niçin aslî olarak bulunmadığını hatta varlıkta yalnızca sırf hayır bulunduğu sorusunu yönelttiklerini söyler. Şehrezurî hukemanın bazısının yönelttiği bu soruya, çok hayır ile bulunan az şer ve tamamen hayır olan içinde şer bulunmayan kısmın aynı olması durumunda aslî olarak şer bulunmayacağını cevap olarak vermektedir. Ayrıca filozof sözlerine Şeceretü'l Illahiyye isimli eserinde şöyle devam eder:

"Senin dediğin niçin birinci kısım ile ikinci kısım aynı değil, niçin ikinci kısım gayr-i nefsi, bu kısma giren cüziyattan olan ateş niçin yaratıldı veya aynı durumda olan diğerleri niçin yaratıldı? Cüziyattan olanlar kötülükleri nefsinde barındırmazlar. Bunların hepsi fasittir, bu kısmın terki az şerre bağlı olan çok hayırdır ki terk olunursa bu durumda ortaya çok kötülük çıkar". ${ }^{104}$

Şehrezurî, ulvî felekî kütlelerin tamamının nuranî olması durumunda, onların nurlarının kevn ve fesad âleminde her şeyi yakacağını savunur. Ona göre eğer şeffaf veya nurdan arî olsaydı, cehenneme dönerdi ve heyula şiddetli bir karanlıkta kalırdı. Yıldızlar ve ışıkları olmasaydı hayvan ve nebatın varlıkları imkânsız olurdu. Nuranî yıldızlar sabit ve hareketsiz olsaydı unsurların şekillerinin olması gerçekleşmezdi. Onun etkileri yok olsaydı şiddetli soğuk, donmuş sular, rutubet gerçekleşirdi ve sonuç olarak hayvan ve nebatat yok olurdu. Nitekim filozof Kasas suresi 71-72. ayeti kerimelerde Allah (c.c.)'ın şöyle buyurduğunu belirtir:"De ki; ne dersiniz? Allah üzerinize kıyamet gününe kadar geceyi sürekli kılsa Allah'tan başka kim hangi ilah size ışığı getirebilir? De ki; ne dersiniz? Allah kıyamet gününe 
kadar gündüzü sürekli kılsa Allah'tan başka hangi ilah dinleneceğiniz geceyi getirebilir? Görmüyor musunuz?". Şehrezurî́ye göre bunların hepsi âlemin düzeninin elde edilmesi, yer ve gökteki harikalıkların, rahmetin tamamlanması, nimetlerin aslı olan kevn ve fesadın devamı için vardır. İnsanların bunların hepsini ihata etmesi mümkün değildir ve insanlar gurbet âlemindedir. Karanlık, ulvî varlıklar, sufî̀ varlıklar nefislerin kahrı altında perdelenmiş; nefisler akılların egemenliği altında, akılların hepsi ilk aklın egemenliği altında ve hepsi egemen olan Allah'ın altında perdelenmişlerdir. Şehrezurî bunlara da delil olarak şu ayetleri verir: "Allah kulları üzerinde hakimiyet sahibidir" (En'am, 18) ve "Allah onları arkalarından kuşatmıştır" (Buruc, 20). ${ }^{105}$

Kısaca İşrakîlerin şer anlayışını özetleyecek olursak şer bizatihi var olan bir şey değildir. Onlara göre metafizik ve fiziksel kötülük eşyanın tam ve mükemmel bir kemal derecesine erişebilme yetkinliğine sahip olmamasından kaynaklanmaktadır. İşrakîler tarafından verilen yukarıda da zikrettiğimiz parmak ile ilgili verilen basit örnek aslında yaratılan evrendeki nizamın tanzim açısından olabilecek en iyi nizam olduğunu göstermektedir. Ahlakî şerlere gelince burada insan yaptıklarından sorumlu olduğu için maddi aleme duyulan iştiyaktan kaynaklanan fiillerinin karşılığını elbette görecektir. İşrakîlere göre Nuru'l Envar'dan sadır olan ilk nur ve devam edegelen nur hiyerarşisi yukarıdan aşağıya üstün mümkünlük ilkesi bağlamında şeref veya hayr derecesini aslında belirlemektedir. Kötülüğün yani şerrin gerçekleştiği yerin kevn ve fesad alemi olduğu görüşünü benimseyen İşrakîler bu alemde de hayrın şerden fazla olduğunu ve aslen maksud olunanın hayr olduğunu savunmaktadırlar. Bundan dolayı da İşrakîler az şerden dolayı daha üstün hayrı terk etmenin daha büyük bir şer olacağını savunurlar.

\section{Sonuç}

Kötülük problemine karşı İslam düşüncesinde verilen cevaplar incelendiğinde her sistemin kendi içerisinde verdiği cevapların bir dayanağı mevcuttur. Verilen bu cevaplar bağlamında İslam kelamında ilahi adalet ön planda iken İslam filozoflarında ilahi inayet ön plana çıkmaktadır. İslam tasavvufunda ise kötülük problemine daha çok nefis gelişimi çerçevesinde cevaplar sunulmuştur.

Kötülük probleminin temelinde Tanrı ve sıfatları, ayrıca bu sıfatların evren ile ilişkisi yatmaktadır. Bundan dolayı verilen cevapları bir tasnife tabi tutarsak ekol ve 
düşünürlerin Tanrı ve evren tasavvurlarına bakmakla beraber Tanrı-evren ilişkisini de göz önünde bulundurmak gerekir. Bundan dolayı İşrakî teodisenin İslam düşüncesi içerisinde hangi alana daha yakın durduğunu gösterebilmek adına İsrakîlerin Tanrı ve evren tasavvurlarından yola çıkmak gerekir.

İşrakî düşüncenin kurmuş olduğu sistem tamamen nur kavramına dayalıdır. İşrakîler, Nuru'I Envar anlayışından hareketle evren tasavvurlarını da nur kavramı üzerine bina etmişlerdir. Bu sistem İslam filozoflarının özellikle Meşşaî ekolde olanların evren tasavvurlarındaki akıllar hiyerarşisi üzerine bina edilmiş olan sudur teorisi ile birtakım kavramsal ve düzensel farklılıklar olmakla birlikte benzerlik de arz etmektedir. Bu hiyerarşide İslam filozoflarının ve Işrakîlerin kötülüğün gerçekleşme alanı olarak gördükleri mahal kevn ve fesad alemi denilen maddî alemdir.

Meşşaîlerin sudur teorisinde de ve İşrakîlerin nur teorisinde de ilk olandan uzaklaşıldıkça yani maddî aleme yaklaşıldıkça değer derecesi varlıklarda düşmektedir. Bu düşüş zatın kemalindeki düşüş anlamına geleceğinden zattaki kemal yoksunluğu da bizatihi var olmayan şerri de maddî alemde ortaya çıkaracaktır.

Genel olarak şer kavramının tanımı, mahiyeti ve buna verilen cevaplara baktığımızda İşrakî düşünce sisteminin kullandığı argümanlar bağlamında İslam filozoflarının kullandığı argümanlar ile açıkça benzerlik arz ettiğini ifade edebiliriz. Fakat argümanlar benzerlik göstermekle birlikte Işrakî düşünce sisteminin temelini oluşturan nur kavramı İşrakîlerin ortaya koydukları teodisede de önemli bir yer tuttuğundan dolayı bu bağlamda özgün bir anlayış ortaya koyduklarını da ifade edebiliriz.

\section{Kaynakça}

Alper, Ömer Mahir. İslam Felsefesinde Akıl-Vahiy Felsefe-Din Ilişkisi. İstanbul: Ayışığı Yayınları, 2000.

Aydın, Mehmet. Din Felsefesi. 9. Baskı. İzmir: İlahiyat Fakültesi Vakfı Yayınları, 2001.

Çağrıcı, Mustafa. İslam Düşüncesinde Ahlak. İstanbul: Dem Yayınları, 2006.

Çağrıcı, Mustafa. "Şer". Türkiye Diyanet Vakfı İslam Ansiklopedisi. 38: 542-544. İstanbul: TDV Yayınları, 2010.

Çelebi, İlyas. "Hüsün ve Kubuh". Türkiye Diyanet Vakfı İslam Ansiklopedisi. 19: 59-63. İstanbul: TDV Yayınları, 1999.

ed-Devvani, Celaleddin. Şevâkilü'l-hûr fi şerhi Heyâkili'n-nûr li's-Sühreverdi. thk. Muhammed Abdülhak, Muhammed Kokan. Bağdat: Beytü'l-Verrak, 2010.

el-Eş'arî, Ebu'l-Hasen. el-ibâne ve usûlü Ehli's-sünnet (Eşari Akaidi). çev. Ramazan Biçer. İstanbul: Gelenek Yayınları, 2010. 
el-isfahâni, Râgıb. Müfredât- Kur'ân Kavramları Sözlüğü. çev. Yusuf Türker. İstanbul: Pınar Yayınları, 2012.

Fârâbî. Ihsâu'l-ulûm (illimlerin Sayımı). çev. Ahmet Arslan. Ankara: Vadi Yayınları, 1999.

Fârâbî. “Risâle fi'l-ilmi'l-ilâhî”. çev. Fehrullah Terkan. Divan Dergisi 1 (2006): 185- 226.

Filiz, Şahin. İslam Felsefesinde Mistik Bilginin Yeri. 2. Baskı. İstanbul: Say Yayınları, 2014.

Gölcük, Şerafeddin, Süleyman Toprak. Kelam/Tarih-Ekoller-Problemler. Konya:Tekin Kitabevi, 2011.

Hume, David. Din Üstüne. çev. Mete Tunçay. 4. Baskı. Ankara: Imge Kitabevi Yayınları, 2004.

İbn Rüşd. Faslu'I-makâl el-Keşf an minhâci'l-edille (Felsefe-Din IIlişkileri). çev. Süleyman Uludağ. İstanbul: Dergâh Yayınları, 1985.

İbn Rüşd. Tehafüt-ü Tehafüt (Tutarsızığın Tutarsızlığı). çev. Muharrem Hilmi Özev. İstanbul: Bordo Siyah Klasik Yayınları, 2006.

İbn Sina. Risaleler. çev. Alpaslan Açıkgenç, M. Hayri Kırbaşoğlu. Ankara: Kitabiyat Yayınları, 2004.

İbn Sina. Kitabu'ş-Şifa: Metafizik. çev. Ekrem Demirli. İstanbul: Litera Yayıncılık, 2005.

IIlhan, Avni. "Aslah". Türkiye Diyanet Vakfı İslam Ansiklopedisi. 3: 495-496. İstanbul: TDV Yayınları, 1991.

Kaya, Mahmut. İslam Filozoflarından Felsefe Metinleri. 3. Baskı. İstanbul: Klasik Yayınları, 2005.

Kaya, Mahmut. "Sudûr". Türkiye Diyanet Vakfı İlam Ansiklopedisi. 37: 467-468. İstanbul: TDV Yayınları, 2009.

Kazanç, Fethi Kerim. “Tanrı ve Kötülük: Kelami Düşünce Geleneğinde Kötülük Problemi Üzerine Bazı Değerlendirmeler". EKEV Akademi Dergisi 35 (2008): 11-32.

Kazeruni, Mahmud b. Mes'ud. Şerhu Hikmeti'Iişrak-ı Sühreverdi. nşr. Abdullah Nurani, Mehdi Muhakkik. Tahran: Encümen-i Asar ve Mefahir-i Ferhengi, 2005.

Leibniz, Gottfried Wilhelm. Theodicee, çev. Levent Özşar. İstanbul: Biblos Kitabevi, 2009.

Manafov, Rafiz. "Meşşai Felsefe ve Kelam Düşüncesinde Adl-i Illahi Meselesi". Selçuk Üniversitesi Illahiyat Fakültesi Dergisi 28 (2009): 32-51.

Mâtürîdî. Kitâbu't-Tevhid. haz. Bekir Topaloğlu, Muhammed Aruçi. Ankara: ISAM Yayınları, 2005.

Natanzî, İzzeddîn Mahmûd bin Ali Kâşânî. Misbâhu'I-hidâye ve miftâhu'l-kifâye (Tasavvufun Ana Esasları). Farsçadan çev. Hakkı Uygur. 2. Basım. İstanbul: Kurtuba Kitap, 2012.

Ormsby, Eric Lee. İslam Düşüncesinde Illahi Adalet Sorunu. çev. Metin Özdemir. Ankara: Kitabiyat Yayınları, 2001.

Özdemir, Metin. İslam Düşüncesinde Kötülük Problemi. İstanbul: Furkan Kitaplığı, 2001.

Özden, H. Ömer. "ibn Sina ve Leibniz'de Kötülük Problemi". Atatürk Üniversitesi Ilahiyat Fakültesi Dergisi 13 (2010): 269- 286.

Özsoy, Ömer, İlhami Güler. Konularına Göre Kuran (Sistematik Kuran Fihristi). Ankara: Fecr Yayınları, 2004.

Sarığlu, Hüseyin. İbn Rüşd Felsefesi. İstanbul: Klasik Yayınları, 2003.

Sühreverdi. Kitabu'I-lemehât. thk. Emil Ma'luf. 2. Baskı. Beyrut: Dârü'n-Nehar li'n-Neşr, 1991.

Sühreverdî. Hikmetu'l-işrâk. Mecmua-i musannefât-ı Şeyhi'l-işrâk içerisinde. tsh. Henry Corbin. 2. Cilt. Tahran: Pejûheşgah-ı Ulum-u İnsani ve Motaleat-ı Ferhengi, 2001/1380. 
Sühreverdî. el-Elvâhu'l-Imadiyye. Mecmua-i musannefât-ı Şeyhi'l-işrâk içerisinde. tsh. Necefkuli Habibi. 4. Cilt. Tahran: Pejûheşgah-ı Ulum-u Insani ve Motaleat-ı Ferhengi, 2001/1380.

Sühreverdî. Makâmâtu's-sûfiyye. thk. Emil Ma'luf. Beyrut: Dâru'l-Maşrik, 2002.

Sühreverdî. Heyâkilu'n-nur. takdim Ahmet Abdürrahim Sayih, Tevfik Ali Vehbe. Kahire: Mektebetü's-Sekâfeti'd-Dîniyye, 2009.

Şehrezurî. Şerhu Hikmeti'liş̧râk. trc. Hasan Ziyai Terbeti. Tahran: Müessese-i Mütalaat ve Tahkikat-ı Ferhengi, 1993.

Şehrezûrî. eş-Şeceretü'l-ilâhiyye fi ulûmi'l-hakâiki'r-rabbâniyye. thk. Necip Görgün. İstanbul: Elif Yayınları, 2004.

Taylan, Necip. Düşünce Tarihinde Tanrı Sorunu. İstanbul: Ayışığı Yayınları, 1998.

Taylan, Necip. İslam Düşüncesinde Din Felsefeleri. İstanbul: M. Ü. Vakfı Yayınları, 2013.

Tunç, Cihat. Kelam IIminin Tarihçesi ve Illk Kelam Okulları. Kayseri: Netform Matbaacılık, 2001.

Turhan, Kasım. Bir Ahlak Problemi Olarak Kelam ve Felsefe Açııından Insan Fiilleri. İstanbul: M. Ü. Vakfı Yayınları, 1996.

Uludağ, Süleyman. "Hicab". Türkiye Diyanet Vakfı İslam Ansiklopedisi. 17: 430-431. İstanbul: TDV Yayınları, 1998.

Uludağ, Süleyman. "Ma'rifet-i Nefs". Türkiye Diyanet Vakfı Islam Ansiklopedisi. 28: 56-57. Ankara: TDV Yayınları, 2003.

Uludağ, Süleyman. “Nefis". Türkiye Diyanet Vakfı İlam Ansiklopedisi. 32: 526-529. İstanbul: TDV Yayınları, 2006.

Yaran, Cafer Sadık. Kötülük ve Teodise. Birinci Basım. Ankara: Vadi Yayınları, 1997.

Yavuz, Yusuf Şevki. "Şer". Türkiye Diyanet Vakfı Islam Ansiklopedisi. 38: 539-542. İstanbul:TDV Yayınları, 2010.

Yüksel, Emrullah. "Illahi Fiillerde Hikmet". Atatürk Üniversitesi Illahiyat Fakültesi Dergisi 8 (1988): 43-76. 
